\title{
Cell Division in a Mutant of Salmonella typhimurium which is Temperature-sensitive for DNA Synthesis
}

\author{
By B. G. SPRATT AND R. J. ROWBURY \\ Department of Botany and Microbiology, University College London, \\ Gower Street, London W.C. I \\ (Accepted for publication 7 January 197 I)
}

\section{SUMMARY}

In Salmonella typhimurium PG I54 the time taken for a round of DNA replication $(C)$ at $37^{\circ}$ is approximately $48 \mathrm{~min}$. The time between the end of a round of DNA replication and the following cell division $(D)$ is approximately $25 \mathrm{~min}$. at $37^{\circ}$. In a temperature-sensitive mutant of $S$. typhimurium defective in the initiation of DNA synthesis, cell division at the restrictive temperature occurs at an approximately normal rate for $75 \mathrm{~min}$., suggesting that $C+D=75$ min.; the cells then elongate and form filaments. After about a further $\mathrm{r} h$. in minimal medium at $38^{\circ}$ cell division recommences at the ends of the filaments to form small cells. Filaments can divide at each end to produce more than one small cell. Once formed, small cells do not grow further. They do not synthesize DNA, RNA or protein and contain little DNA. Complete inhibition of DNA synthesis at the time of the shift stops cell division within about $D$ min. and almost completely stops the production of small cells. A period of growth at $38^{\circ}$ before the inhibition of DNA synthesis allows more division and the production of an almost normal number of small cells. Both the early divisions and the production of small cells are considered to be the result of the termination of rounds of DNA replication in the absence of new initiations.

\section{INTRODUCTION}

Although bacterial cells usually contain only one or two nuclear bodies, cells lacking DNA are extremely rare under normal conditions (Hirota et al. I968a). This has suggested to many workers that DNA synthesis and cell division are tightly coupled (Kuempel \& Pardee, 1963; Clark, 1968; Walker \& Pardee, 1968). The nature of the relation between DNA replication and cell division has been studied by Helmstetter and his co-workers, who have shown that at growth rates greater than I doubling/ h. at $37^{\circ}$ a constant time elapses between the end of a round of DNA replication and the following cell division (Cooper \& Helmstetter, 1968). At $37^{\circ}$ in Escherichia coli $\mathrm{B} / \mathrm{r}$ this time is about $22 \mathrm{~min}$. and is called the $D$ period. Once a cell has finished a round of replication, division can occur even if further DNA synthesis is inhibited (Clark, I968). Thus inhibition of DNA synthesis results in residual cell division at the normal rate for a further $20 \mathrm{~min}$. (Clark, I968; Helmstetter \& Pjerucci, I968). This residual division is considered to be in cells which were in the $D$ period at the time of inhibition of DNA synthesis.

A second parameter of cell growth studied by Helmstetter and his co-workers (Cooper \& Helmstetter, 1968) is the time required for a round of DNA replication. 
They have shown that at growth rates greater than I doubling/h. a round of DNA replication takes a constant time, $C$. At $37^{\circ}$ in Escherichia coli $\mathrm{B} / \mathrm{r} C$ is about $44 \mathrm{~min}$. As $C$ and $D$ are constants at these growth rates (at a particular temperature), it follows that the rate of cell division is determined by the frequency of initiations of rounds of DNA replication (Maaløe \& Kjeldgaard, 1966).

We have reported a temperature-sensitive mutant of Salmonella typhimurium that appears to be defective in the initiation of DNA synthesis at the restrictive temperature (Spratt \& Rowbury, 1970). In this paper we report the cell division pattern of the mutant at the restrictive temperature and some properties of the small cells produced under these conditions, and compare this behaviour with that predicted by the model of cell growth proposed by Cooper \& Helmstetter (1968) and with the behaviour of other DNA synthesis mutants.

\section{METHODS}

Organisms. Salmonella typhimurium PG I54 was obtained from Dr K. Sanderson and has the following genetic constitution: $\mathrm{F}^{-}$, metA22, tryB2, ilv-9o, xyl-r, fla-66, strA2Io, malAI, tre-I2, $h I-b, h 2-e, n, x$. The mutant I I G was obtained from PG I54 by treatment with $N$-methyl- $N^{\prime}$-nitro- $N$-nitrosoguanidine (Spratt \& Rowbury, 1970).

Media. Nutrient broth (Oxoid NB2) was used as a rich medium. The minimal medium (MM) was that of Davis \& Mingioli (I950) with $0.2 \%$ glucose and $40 \mu \mathrm{g} . / \mathrm{ml}$. of the DL-form of the required amino acids. Difco vitamin-free Casamino acids $(0.1 \%$ ) were added to enrich the $\mathrm{MM}$ in some experiments. These media were solidified with Difco Bacto agar ( $2 \%$ ). For phage assays the basal agar consisted of I \% trypticase agar base, $\mathrm{I} \cdot 4 \%$ Difco Bacto agar and $0.5 \% \mathrm{NaCl}$ with a soft agar overlay of $0.2 \% \mathrm{MgCl}_{2}, \mathrm{I} \%$ Oxoid no. 2 broth, $0.3 \% \mathrm{NaCl}$ and $0.75 \%$ Difco Bacto agar.

Growth of organisms. Organisms were subcultured from nutrient agar slopes into the required medium and incubated overnight in a shaking water-bath. To obtain exponentially growing organisms, such cultures were diluted into fresh medium and incubated for several hours with shaking. Extinction of cultures was measured in a Hilger photoelectric colorimeter against an uninoculated medium blank ( $490 \mathrm{~nm}$. for MM and $550 \mathrm{~nm}$. for nutrient broth). Total cell number was measured using a Coulter model F electronic particle counter. Samples were diluted into Isoton diluent containing $0.1 \%$ sodium azide (Coulter Electronics Ltd), and o. I ml. counted with the $30 \mu \mathrm{m}$. orifice with a threshold of 4 , attenuation $I$ and aperture 8.

Cell division. Cell division was studied either by Coulter-counting or by following the growth of individual cells under the phase-contrast microscope. In the latter case a suitably diluted culture of cells growing exponentially in the required medium at the required temperature was poured on to a thin film of agar (made from the same medium solidified with $2 \%$ Difco Bacto agar). The agar was transferred to a clean microscope slide, kept moist by surrounding the film of agar with blocks of the same agar, covered with a coverslip, and examined at approximately $15 \mathrm{~min}$. intervals under a phase-contrast microscope at $\times 1500$. All the procedures were performed in a constant-temperature room maintained at $38^{\circ}$. The cell-division pattern of 20 to 30 wellseparated cells could be studied in this way and the agar could be kept moist for over 4 h. at $38^{\circ}$.

Synthesis of DNA, RNA and protein. Macromolecular syntheses were measured by 
following the incorporation of $\left[{ }^{3} \mathrm{H}\right]$ thymidine, $\left[{ }^{14} \mathrm{C}\right]$ uracil and $\left[{ }^{4} \mathrm{C}\right]$ phenylalanine as described previously (Spratt \& Rowbury, 1970).

Chemical estimation of DNA. Cell samples for DNA estimation (approximately $10^{10}$ cells) were cooled, centrifuged, washed in cold tris- $\mathrm{HCl}$ buffer $(0.05 \mathrm{M}, \mathrm{pH} 7.5)$, resuspended in $3 \mathrm{ml}$. of $5 \%$ TCA and the DNA extracted at $90^{\circ}$ for $20 \mathrm{~min}$. The supernatant of the extraction was assayed for deoxyribose by the modified diphenylamine method of Giles \& Myers (I965). Calf thymus DNA was extracted similarly and used for a standard curve.

Separation of small cells. Strain I I G was grown in the required medium at $38^{\circ}$ for about $4 \mathrm{~h}$., centrifuged at $3000 \mathrm{rev} . / \mathrm{min}$. for $10 \mathrm{~min}$., washed with $0.05 \mathrm{M}$-tris- $\mathrm{HCl}$

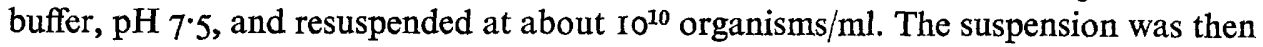
gently layered on to a 5 to $50 \%$ linear sucrose gradient and spun at $1500 \mathrm{rev}$./min. in I $5 \mathrm{ml}$. glass tubes in the swing-out head of a bench centrifuge for $10 \mathrm{~min}$. After this treatment the filaments were in the pellet and in the bottom half of the tube, whereas the small cells formed a homogeneous band in the top half of the tube. The small cells were removed carefully with a sterile syringe. This method of purification of small cells gave a homogeneous preparation with less than I \% contaminating filaments.

Chemicals. Radioisotopes were obtained from the Radiochemical Centre, Amersham, Buckinghamshire, $\left[\mathrm{L}-{ }^{14} \mathrm{C}\right]$ phenylalanine was supplied at $12.6 \mathrm{mCi} / \mathrm{mM},\left[2-{ }^{14} \mathrm{C}\right]$ uracil at $54^{\circ} 9 \mathrm{mCi} / \mathrm{mm}$, and methyl $\left[{ }^{3} \mathrm{H}\right]$ thymidine at $5.0 \mathrm{Ci} / \mathrm{mm}$. Nalidixic acid was kindly donated by the Bayer Products Company.

\section{RESULTS}

\section{Growth parameters of Escherichia coli and Salmonella typhimurium}

The growth parameters $C$ (time for a round of DNA replication) and $D$ (time between the end of a round of DNA replication and the following cell division) have been shown to be useful for describing cellular growth of Escherichia coli (Cooper \& Helmstetter, 1968; Helmstetter, 1969; Marr, Painter \& Nilson, 1969). We have made estimates of $C$ and $D$ for Salmonella typhimurium. $D$ was estimated by measuring the residual cell division after the inhibition of DNA synthesis with nalidixic acid. Fig. I shows the effect of $\mathrm{I} 5 \mu \mathrm{g}$. $/ \mathrm{ml}$. nalidixic acid on cell division in S. typhimurium PG I54 at $37^{\circ}$ in Casamino acid MM and nutrient broth. Fifteen $\mu \mathrm{g} . / \mathrm{ml}$. nalidixic acid stops DNA synthesis immediately in this strain without having very much effect on RNA or protein synthesis. The value for $D$, i.e. the time before residual cell division stops, is between 23 and $26 \mathrm{~min}$. and the residual cell division is about $50 \%$ in Casamino acid MM and $100 \%$ in nutrient broth. Thus in nutrient broth every cell can proceed from birth to division in the absence of DNA synthesis, i.e. the mean generation time in this medium is approximately equal to $D$ (Helmstetter \& Pierucci, I968).

A value for $C$ can be obtained in several ways (see Pritchard \& Zaritsky, 1970). The percentage increment ( $\triangle \mathrm{DNA}$ ) in DNA synthesis after inhibition of protein synthesis by chloramphenicol is given by

$$
\triangle \mathrm{DNA}=\operatorname{roo}\left(\frac{2^{n} n \ln 2}{2^{n}-\mathrm{I}}-\mathrm{I}\right)
$$

(Sueoka \& Yoshikawa, 1965; Donachie, I969) and $n$ can be shown to be equal to $C / \tau$, where $C$ is the time for a round of replication of DNA and $r$ is the growth rate of the organism in the medium used (Pritchard \& Zaritsky, 1970). Salmonella typhi- 
murium growing exponentially with a mean generation time of 27 min. gives $\triangle \mathrm{DNA}=$ $73 \%$ when $150 \mu \mathrm{g}$. $/ \mathrm{ml}$. chloramphenicol is added, and this increment is reached in about 40 min. (Fig. 2). Substituting these values in the equation above gives a value for $C$ of 47 min. for S. typhimurium PG I54 at $37^{\circ}$.

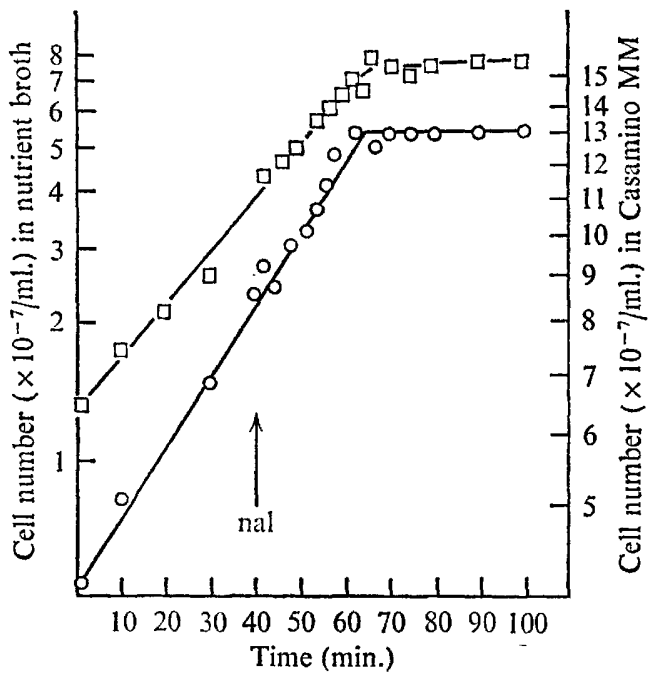

Fig. I

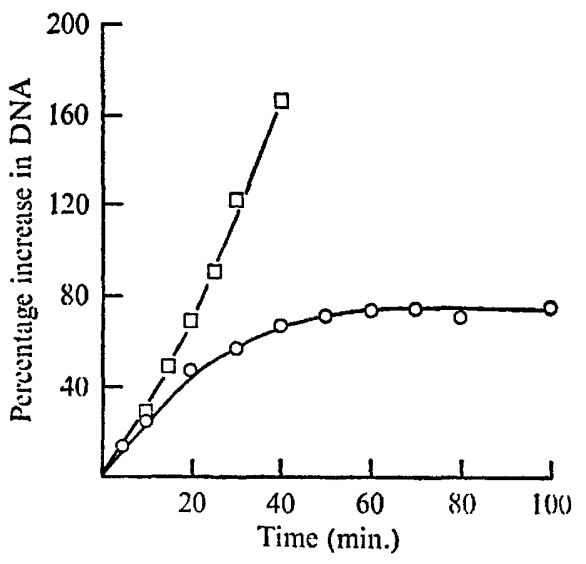

Fig. 2

Fig. I. Effect of DNA synthesis inhibition on cell division in strain PG I54. Cell number was followed using the Coulter counter for cultures of Salmonella typhimurium PG 154 growing exponentially at $37^{\circ}$ in Casamino acid MM (O) and nutrient broth ( $\square$ ). At $40 \mathrm{~min}$. $15 \mu \mathrm{g} . /$ $\mathrm{ml}$. nalidixic acid (nal) was added and cell division followed for a further $60 \mathrm{~min}$.

Fig. 2. The increment in DNA synthesis in strain PG 154 at $37^{\circ}$ in the absence of protein synthesis. A culture of Salmonella typhimurium PG 54 growing exponentially in Casamino acid $\mathrm{MM}+\mathrm{I} \cdot 5 \mathrm{mM}$ uridine at $37^{\circ}$ was split into two portions. $\left[{ }^{3} \mathrm{H}\right]$ Thymidine was added at $0.2 \mu \mathrm{Ci} / 0.2 \mu \mathrm{g} . / \mathrm{ml}$. and incorporation followed at $37^{\circ}$ in the presence $(0)$ and in the absence ( $\square$ ) of $\mathrm{I} 50 \mu \mathrm{g} . / \mathrm{ml}$. chloramphenicol.

A second value for $C$ can be obtained by knowing $D$ and the DNA content per cell at a particular growth rate and using the equation

$$
\bar{G}=\frac{\tau}{C \ln 2}\left(2^{(C+D) / \tau}-2^{D / \tau}\right)
$$

(Cooper \& Helmstetter, I968), where $\bar{G}$ is the DNA content per cell in genome equivalents. To obtain $\bar{G}$ the DNA content of a non-replicating genome must be known. Cooper \& Helmstetter (1968) give a value of $4.2 \times 10^{-15} \mathrm{~g}$./genome for Escherichia coli $\mathrm{B} / \mathrm{r}$ and the value for Salmonella typhimurium is probably almost identical, as Maaløe $\&$ Kjeldgaard (I966) give a value of 4 to $5 \times 10^{-15} \mathrm{~g}$./genome. We have used the value of $4.2 \times 10^{-15} \mathrm{~g}$./genome for calculating $\bar{G}$. Salmonella typhimurium PG I54 growing exponentially at $37^{\circ}$ was harvested and the DNA/cell measured as described in Methods. At a mean generation time of $29.5 \mathrm{~min}$. at $37^{\circ}$ we obtained a DNA content of $14.2 \times 10^{-15} \mathrm{~g}$./cell (DNA expressed as free acid). This gives a value for $C$ of $49 \mathrm{~min}$. based on $D=25 \mathrm{~min}$. 


\title{
Effect of inhibition of DNA synthesis on cell division in strain II G
}

Cell division in Salmonella typhimurium PG I 54 stops after a 25 min. residual division period at $37^{\circ}$, when DNA synthesis is stopped with nalidixic acid. When DNA synthesis is stopped in strain I I G by shifting a culture from $25^{\circ}$ to $38^{\circ}$ cell division continues for several hours. In MM at $38^{\circ}$ nearly all the cells are seen to divide once under the phasecontrast microscope and to produce two apparently normal daughter cells (Table I) which both elongate to form short filaments, able to divide terminally forming a shorter filament and a small cell. In nutrient broth at $38^{\circ}$ most cells of I I G are able to divide twice and produce four apparently normal daughter cells (Table $I$ ) which elongate and start to divide at the ends in the same way as the MM grown cells. Some of these daughter cells produced in the early divisions must be viable as the viable count increases during the first hour at $38^{\circ}$ before falling off exponentially (Spratt \& Rowbury, 1970). Studies with the Coulter counter show that a culture of I I G in MM when

\section{Table I. Division of individual cells of $I_{I} G$ on solid media}

\begin{abstract}
Organisms growing exponentially in liquid media at $25^{\circ}$ were shifted to the same solid media at $38^{\circ}$ and cell division of individual cells followed as described in Methods. In the experiments with nalidixic acid the solid media contained $25 \mu \mathrm{g}$. $/ \mathrm{ml}$. nalidixic acid. In all cases the division of more than 50 cells was followed. Small cells were those that were produced terminally and which failed to increase in size. Median 'normal' divisions were those that produced two equal-sized daughter cells that both grew further.
\end{abstract}

\begin{tabular}{|c|c|c|c|c|c|c|}
\hline \multirow[b]{2}{*}{ Medium } & \multicolumn{5}{|c|}{ Number of normal divisions (\%) } & \multirow{2}{*}{$\begin{array}{l}\text { Normal } \\
\text { daughter } \\
\text { cells } \\
\text { producing } \\
\text { small cells }(\%)\end{array}$} \\
\hline & 0 & $\mathbf{I}$ & 2 & 3 & 4 & \\
\hline MM & I5 & 77 & 8 & o & 0 & 39 \\
\hline Casamino MM & 10 & 34 & $5 \mathrm{I}$ & 5 & 0 & - \\
\hline Nutrient broth & 3 & 29 & 53 & I5 & 0 & 52 \\
\hline Nutrient broth + nalidixic acid & $6 \mathrm{I}$ & 39 & 0 & 0 & 0 & 5 \\
\hline $\begin{array}{l}\text { Nutrient broth }+ \text { nalidixic acid } \\
\text { added after } 60 \text { min. at } 38^{\circ}\end{array}$ & 一 & - & - & - & - & 48 \\
\hline
\end{tabular}

shifted from $25^{\circ}$ to $38^{\circ}$ continues to increase in cell number for about $75 \mathrm{~min}$; ; cell number then remains static for about another $70 \mathrm{~min}$. and then increases again (Fig. 3). The plateau value reached after $75 \mathrm{~min}$. represents an increase of $160 \%$ in cell number over the number present at the time of the shift in this medium. During the initial 75 min. period nearly all cells can be observed under the microscope to divide once (the extent of division appears to be slightly greater in liquid medium than on agar) and the increase in cell number after I $40 \mathrm{~min}$. represents the recommencement of cell division after the period of elongation. As the growth rate afforded by the medium increases, so the amount of cell division in the first $75 \mathrm{~min}$. after the shift increases and the production of small cells occurs earlier until in nutrient broth the plateau at $75 \mathrm{~min}$. is only seen as a shoulder in the curve (Fig. 3). The value of the shoulder in nutrient broth represents an increase in cell number of about $300 \%$, corresponding to the direct microscopic observation that nearly all cells can divide twice in this medium after a shift to $38^{\circ}$, before the production of small cells. 
Effect of chemical inhibition of DNA synthesis on cell division in strain II G at $38^{\circ}$

Strain I I G after a shift from $25^{\circ}$ to $38^{\circ}$ continues DNA synthesis for about $40 \mathrm{~min}$., resulting in the termination of rounds of DNA replication in the absence of new initiations of DNA synthesis (Spratt \& Rowbury, 1970). If the termination of rounds of DNA replication is necessary for the continuing cell division at $38^{\circ}$, then immediate inhibition of DNA synthesis with nalidixic acid at the time of the temperature shift should drastically reduce the amount of cell division. In fact cell division should stop within about $D$ min. Table I shows the effect on cell division of shifting I I G growing in nutrient broth at $25^{\circ}$ to nutrient agar plates at $38^{\circ}$ containing $25 \mu \mathrm{g}$. $/ \mathrm{ml}$. nalidixic

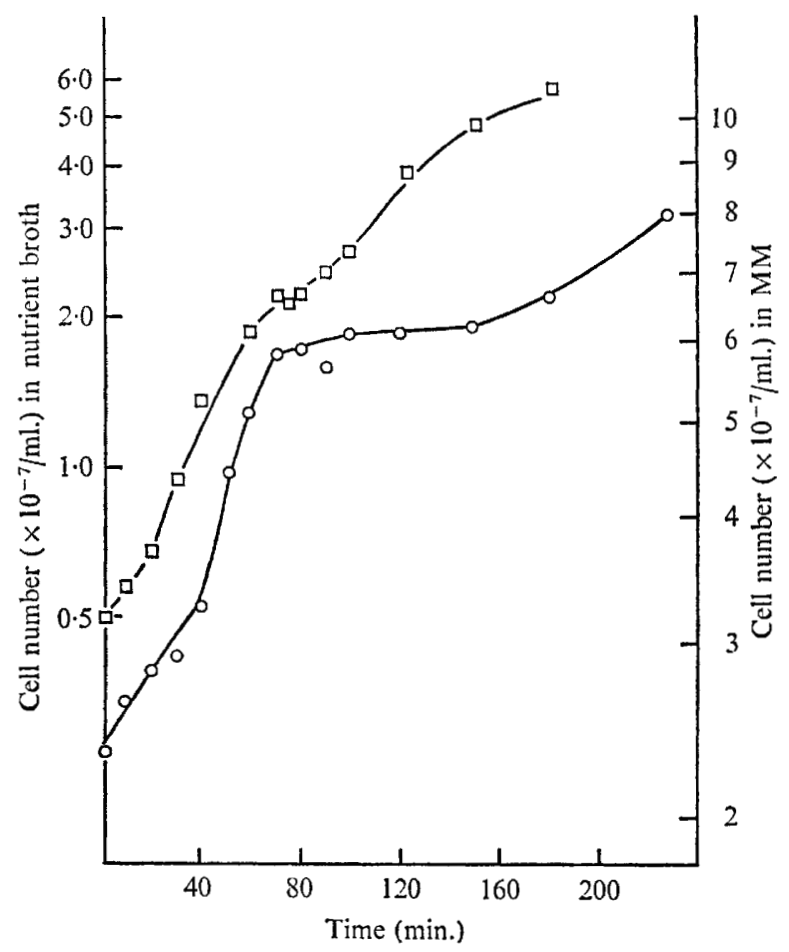

Fig. 3. Cell division in strain I I G at $38^{\circ}$. Cell number was followed using the Coulter counter for cultures of strain II G growing exponentially in MM (O) and nutrient broth ( $\square$ ) after a shift from $25^{\circ}$ to $38^{\circ}$.

acid. None of the cells can divide more than once, whereas without nalidixic acid $68 \%$ of cells can divide twice or three times. These cells that do divide in the presence of nalidixic acid were presumably in the $D$ period at the time of the shift. The $6 \mathrm{I} \%$ of cells that fail to divide would not be in a $D$ period. The addition of nalidixic acid at the time of the temperature shift reduces the number of small cells produced from $52 \%$ to $5 \%$. In liquid media plus $15 \mu \mathrm{g}$. $/ \mathrm{ml}$. nalidixic acid at $38^{\circ}$ residual cell division continues for about $D$ min. as expected (data not shown).

Thus the termination of rounds of DNA replication in II G at $38^{\circ}$ would seem to be necessary for continued cell division. If the termination of rounds is not only responsible for the normal divisions but also is involved in the subsequent production of small 
cells at $38^{\circ}$ then a period of growth at $38^{\circ}$ before the addition of nalidixic acid should allow rounds to be finished and the production of small cells. Table I shows that $60 \mathrm{~min}$. growth at $38^{\circ}$ before addition of nalidixic acid allows the almost normal production of small cells.

\section{Properties of small cells}

Small cells were separated by sucrose density centrifugation from a culture obtained by growing II G at $38^{\circ}$ in nutrient broth for $4 \mathrm{~h}$. The small cells, washed to remove sucrose and resuspended in nutrient broth, showed no increase in extinction when shaken at $38^{\circ}$ for at least $2 \mathrm{~h}$. Similarly, DNA, RNA and protein synthesis in purified small cells was negligible. Incorporations of $\left[{ }^{3} \mathrm{H}\right]$ thymidine, $\left[{ }^{14} \mathrm{C}\right]$ uracil and $\left[{ }^{14} \mathrm{C}\right]$ phenylalanine in the small cells at $38^{\circ}$ were $0,0.6$ and $\mathrm{I} \cdot \mathrm{I} \%$ respectively compared with that in strain PG 154 for the same initial cell density during a $2 \mathrm{~h}$. period.

Less than $0.5 \%$ of the small cells formed colonies on nutrient agar at $25^{\circ}$. These few colonies were probably due to contaminants obtained during the purification of the small cells, to temperature-resistant revertants of II G which would band with the small cells in the sucrose gradient and to small filaments.

DNA Content of small cells. Three methods were used to determine whether the small cells derived from strain II G after growth at $38^{\circ}$ contained any DNA. First, DNA was estimated chemically by the modified diphenylamine assay (Giles \& Myers, I965); secondly, we measured the retention in small cells of radioactivity from cells of I I G previously labelled at $25^{\circ}$ with $\left[{ }^{3} \mathrm{H}\right]$ thymidine; and thirdly, thin sections of the small cells were examined in the electron microscope. All methods indicated a reduced DNA content in the small cells and electron microscopy demonstrated the absence of discrete nuclear bodies.

\section{DISCUSSION}

It would seem that the regulation of the growth of Salmonella typhimurium can be described by the same growth parameters as Escherichia coli. The data of Schaechter, Maaløe \& Kjeldgaard (1958) on DNA contents of $S$. typhimurium at different growth rates fits well with the theoretical curves and the experimental results of Cooper $\&$ Helmstetter (1968). Our values of $C$ and $D$ for $S$. typhimurium PG I54 are also very similar to those of $E$. coli $\mathrm{B} / \mathrm{r}$. Similarly, a value for $C+D$ of 60 to $70 \mathrm{~min}$. can be obtained from the data of Kjeldgaard, Maaløe \& Schaechter (1958) (Pritchard, Barth \& Collins, 1969). We would consider that the model derived by Cooper \& Helmstetter (1968) for E. coli can be usefully employed for describing and predicting the growth behaviour of $S$. typhimurium.

Since the temperature-sensitive lesion in strain IIG is in the initiation of DNA replication (Spratt \& Rowbury, 1970), we would predict that cell division after a shift from $25^{\circ}$ to $38^{\circ}$ would continue for $C+D$ min., i.e. any cells that had initiated a round of DNA replication before the shift + any cells in the $D$ period at the time of the shift would be able to divide. The last cells to divide would be those that had just started a round of DNA replication at the time of the shift. These cells would finish the round $C$ min. after the shift and then divide after a further $D \mathrm{~min}$. This is the actual behaviour of strain I I G when shifted to $38^{\circ}$ (Fig. 3) and this suggests that the DNA lesion in I I G does not affect cell division per se. Furthermore, the extent of cell division before the 75 min. plateau is reached after growth in different media supports the view that 
rounds of replication are completed at the restrictive temperature and that normal segregation occurs. Further evidence that the $75 \mathrm{~min}$. residual cell division is due to the termination of rounds of DNA replication in II G at $38^{\circ}$ is suggested by the cell division pattern in the presence of nalidixic acid. Immediate inhibition of DNA synthesis at the time of the shift should result in a drastic reduction in cell division. This is seen to occur (Table $\mathrm{I}$ ).

The recommencement of cell division and the production of small cells would also seem to be connected to the residual DNA synthesis in II $G$ at $38^{\circ}$, since small cell production is almost nil if nalidixic acid is added at the time of the temperature shift from $25^{\circ}$ to $38^{\circ}$ whereas if nalidixic acid is added after a period of growth at $38^{\circ}$ (allowing rounds of replication to be completed) an almost normal number of small cells can be produced. Hirota, Ryter \& Jacob (I968 b) have shown that in two temperature-sensitive DNA synthesis mutants of Escherichia coli the production of DNA-less cells is the result of a second mutation (div). We have no evidence that strain IIG contains two lesions but a search (at present in progress) among $t s^{-}$recombinants from genetic crosses for the loss of the ability to produce DNA-less cells should clarify the matter.

In MM, according to the model of Cooper \& Helmstetter (1968), Escherichia coli $\mathrm{B} / \mathrm{r}$ has a chromosome with a single replication point. If this model is applied to the behaviour of strain $11 \mathrm{G}$, inhibition of the initiation of DNA synthesis at $38^{\circ}$ should result in the production of two completed chromosomes in MM. Within the first $75 \mathrm{~min}$. at $38^{\circ}$ in MM nearly all cells divide once and this would result in the segregation of the two completed chromosomes, one per daughter cell. Any further cell division should result in the production of cells lacking DNA. The fact that the small cells, in contrast to the filaments, fail to grow at $38^{\circ}$ supports this interpretation. Results of three methods to detect DNA show that the small cells have little DNA. These small cells, as expected, fail to synthesize DNA, RNA or protein.

$F^{\prime}$ derivatives of strain IIG fail to form colonies at $38^{\circ}$, but are able to transfer poorly the $F^{\prime}$ into $F^{-}$recipients and to segregate the episome into small cells at $38^{\circ}$ (R. J. Rowbury \& B. G. Spratt, unpublished). Thus some transfer and segregation of the independent $F^{\prime}$ replicon can occur at $38^{\circ}$ in the absence of chromosomal DNA synthesis, a result similar to that obtained with the segregation of $F$-primes into minicells in the minicell-producing strain (Adler, Fisher, Cohen \& Hardigree, 1967), where chromosome segregation is abnormal (Kass \& Yarmolinsky, 1970).

The fact that strain I I $G$ behaves as predicted by the model of Cooper \& Helmstetter (I968) suggests that the lesion in DNA synthesis in I I G is not affecting cell division per se. We also believe that the cell division pattern of strain I I G is further evidence that it is the termination of rounds of DNA replication that is required for the triggering of cell division. Some DNA synthesis mutants behave, as regards cell division, in accordance with this model (Clark, 1968; Fangman \& Novick, 1968; Gross, Karamata \& Hempstead, 1968). Other DNA synthesis mutants would seem to be affected in a function that is common to DNA synthesis and cell division (Inouye, 1969; Khatchatourians \& Clark, 1970). The cell division pattern of the temperaturesensitive DNA synthesis initiation mutants of Hirota et al. (1968a) is not clear from the literature. Strains T 46 and $\mathrm{T} 83$ of Hirota et al. (1968b) seem to be affected in a common function (Shapiro, Siccardi, Hirota \& Jacob, 1970) but they do differ in that $\mathrm{T} 46$ has a div mutation and $\mathrm{T} 83$ has not. Khatchatourians \& Clark (1970) briefly 
report that $\mathrm{T} 83$ fails to divide at the restrictive temperature but can be made to divide to a certain extent at the restrictive temperature by osmotic shock. These authors suggest that the lesion in $\mathrm{T} 83$ is in a factor that is involved in both the initiation of DNA synthesis and in cell division. The observation (B. G. Spratt \& R. J. Rowbury, unpublished) that the $t s$ lesion in II G maps some distance to the right of met $A$ on the Salmonella genetic map suggests that the lesion in II G is different from that in $\mathrm{T} 83$ and $\mathrm{T} 46$.

One of us (B. G.S.) acknowledges the receipt of a Science Research Council Studentship.

\section{REFERENCES}

AdLer, H. I., Fisher, W. D., COHEN, A. \& HARdigree, A. A. (1967). Miniature Escherichia coli cells deficient in DNA. Proceedings of the National Academy of Sciences of the United States of America 57, 321-326.

Clark, D. J. (I968). The regulation of DNA replication and cell division in E. coli B/r. Cold Spring Harbor Symposia on Quantitative Biology 33, 823-838.

COOPER, S. \& HeLMSTETter, C. E. (I968). Chromosome replication and the cell division cycle of Escherichia coli $\mathrm{B} / \mathrm{r}$. Journal of Molecular Biology 3I, 519-540.

Davis, B. D. \& MingIOLI, E. S. (I950). Mutants of Escherichia coli requiring methionine or vitamin $\mathrm{B}_{12}$. Journal of Bacteriology 60, 17-28.

DonachIE, W. D. (1969). Control of cell division in Escherichia coli: Experiments with thymine starvation. Journal of Bacteriology 100, 260-268.

Fangman, W. L. \& Novick, A. (1968). Characterization of two bacterial mutants with temperaturesensitive synthesis of DNA. Genetics 6o, I-I7.

GILES, K. W. \& MYERS, A. (1965). An improved diphenylamine method for the estimation of deoxyribonucleic acid. Nature, London 206, 93.

Gross, J. D., Karamata, D. \& Hempstead, P. G. (1968). Temperature-sensitive mutants of Bacillus subtilis defective in DNA synthesis. Cold Spring Harbor Symposia on Quantitative Biology 33, 307-3I2.

HeLmSTETTER, C. E. (1969). Regulation of chromosome replication and cell division in Escherichia coli. In The Cell Cycle: Gene-enzyme Interactions, pp. 15-35. Edited by G. M. Padilla, G. L. Whitson \& I. L.Cameron. London and New York: Academic Press.

Helmstetter, C.E. \& PieruCCI, O. (1968). Cell division during inhibition of deoxyribonucleic acid synthesis in Escherichia coli. Journal of Bacteriology 95, 1627-1633.

Hirota, Y., JACOB, F., Ryter, A., Buttin, G. \& NAKAI, T. (I968a). On the process of cellular division in bacteria. I. Asymmetrical cellular division and DNA-less bacteria in Escherichia coli. Journal of Molecular Biology 35, 175-192.

HiRotA, Y., RYTER, A. \& JACOB, F. (1968b). Thermosensitive mutants of E. coli affecting the processes of DNA synthesis and cellular division. Cold Spring Harbor Symposia on Quantitative Biology 33, 677-693.

INOUYE, M. (1969). Unlinking of cell division from deoxyribonucleic acid replication in a temperaturesensitive deoxyribonucleic acid synthesis mutant of Escherichia coli. Journal of Bacteriology 90, $842-850$.

KASS, L. R. \& YARMOLINSKY, M. B. (1970). Segregation of functional sex factor into minicells. Proceedings of the National Academy of Sciences of the United States of America 66, 815-822.

Khatchatourians, G. G. \& Clark, D. J. (1970). Regulation of cell division and DNA replication in E. coli. Bacteriological Proceedings, p. 7I.

KJeldgaARd, N. O., MaAløe, O. \& Schaechter, M. (1958). The transition between different physiological states during balanced growth of Salmonella typhimurium. Journal of General Microbiology 19, 607-616.

Kuempel, P. L. \& PARdeE, A. B. (1963). The cycle of bacterial duplication. Journal of Cellular and Comparative Physiology 62, Suppl. I, 15-30. 
MaAløe, O. \& KJeldegaARd, N. O. (1966). Control of Macromolecular Synthesis. New York: W. A. Benjamin.

Marr, A. G., Painter, P. R. \& Nilson, E. H. (1969). Growth and division of individual bacteria. Symposia of the Society for General Microbiology 19, 237-261.

Pritchard, R. H., Barth, P. T. \& Collins, J. (1969). Control of DNA synthesis in bacteria. Symposia of the Society for General Microbiology 19, 263-297.

PrITCHARD, R. H. \& ZARITSKY, A. (1970). Effect of thymine concentration on the replication velocity of DNA in a thymineless mutant of Escherichia coli. Nature, London 226, 126-131.

Schaechter, M., MAaløe, O. \& KJeldgaARd, N. O. (1958). Dependence on medium and temperature of cell size and chemical composition during balanced growth of Salmonella typhimurium. Journal of General Microbiology x9, 592-606.

Shapiro, B. M., SicCARdi, A. G., Hirota, Y. \& JACOB, F. (1970). On the process of cellular division in Escherichia coli. II. Membrane protein alterations associated with mutations affecting the initiation of DNA synthesis. Journal of Molecular Biology 52, 75-89.

SpratT, B. G. \& RowbuRY, R. J. (1970). A mutant in the initiation of DNA synthesis in Salmonella typhimurium. Journal of General Microbiology 64, 127-1 38.

SueoKa, N. \& Yoshikawa, H. (1965). The chromosome of Bacillus subtilis. I. Theory of marker frequency analysis. Genetics $\mathbf{5 2}, 747-757$.

WALKeR, J. R. \& PARDEe, A. B. (1968). Evidence for a relationship between deoyxribonucleic acid metabolism and septum formation in Escherichia coli. Journal of Bacteriology 95, 123-13I. 